\title{
Clinical Reasoning: A case of bilateral foot drop in a 74-year-old man
}

Yohei Harada, MD, Stephan L. Zuchner, MD, David N. Herrmann, MBBCh, and Aravindhan Veerapandiyan, MD Neurology ${ }^{\circledR}$ 2020;94:405-409. doi:10.1212/WNL.0000000000008760
Correspondence

Dr. Veerapandiyan

aveerapandiyan@uams.edu

\section{Section 1}

A 74-year-old man with no relevant medical history presented with 5 years of slowly progressive bilateral foot drop. He had used ankle foot orthoses for 3 years prior to presentation. There was no report of upper extremity weakness, numbness, paresthesia, myalgias, muscle cramps, or stiffness. He had attained age-appropriate developmental milestones as a child and was athletic, keeping up with his peers. His mother had bilateral foot drop, ankle contractures, and difficulty with ambulation. His brother, 2 daughters, and a son lacked similar symptoms. Neurologic examination showed bilateral distal lower extremity weakness (Medical Research Council grade $0 / 5$ ankle dorsiflexion and eversion and grade 4/5 ankle plantar flexion and inversion), symmetric distal leg and intrinsic foot muscle wasting, absent patellar and Achilles tendon reflexes, and a steppage gait. Tone was reduced at bilateral ankles. Sensory examination including light touch, pinprick, vibration, and proprioception was intact. Mild bilateral pes cavus and hammertoes were noted. The remainder of the neurologic and physical examination was normal.

\section{Questions for consideration:}

1. What is the differential diagnosis?

2. What investigations should be considered?

GO TO SECTION 2 


\section{Section 2}

Foot drop is primarily caused by the weakness of the tibialis anterior muscle that produces ankle dorsiflexion. A systematic approach through anatomical localization is critical to determine the origin of foot drop. CNS disorders involving the brain or spinal cord uncommonly manifest with pure, bilateral foot drop. The tibialis anterior muscle is predominantly innervated by the L 5 nerve root. Spinal cord lesions above L5 can cause bilateral foot drop. However, the absence of upper motor neuron signs or other features of spinal cord dysfunction in our patient argue against these. Anterior horn cell disorders also cause foot drop. Amyotrophic lateral sclerosis is unlikely due to the absence of upper motor neuron signs, fasciculations or bulbar involvement, and the very slow rate of progression. Progressive muscular atrophy that only affects lower motor neurons commonly presents with asymmetrical segmental involvement, though symmetrical involvement of distal muscles has been described. ${ }^{1}$ Bilateral L5 radiculopathies or lumbosacral plexopathy may also cause bilateral foot drop. However, the absence of sensory symptoms, pain, or weakness in proximal L5 myotomes in our patient is atypical. Peripheral nerve lesions involving bilateral sciatic or peroneal (fibular) nerves that innervate the tibialis anterior muscles is a possibility. The peroneal nerves are susceptible to compression at the fibular head. Associated sensory involvement is typically seen. A lack of a history suggesting compression of the peroneal nerves, the absence of sensory symptoms or signs, and the associated ankle inversion and plantar flexion weakness (innervated by the tibial nerve) make compression at the fibular head an unlikely etiology. Similarly, the absence of sensory findings or hamstring weakness argue against a localization to the sciatic nerves. Polyneuropathy (hereditary or acquired) is also a common cause of foot drop. The pure motor clinical phenotype limits the range of possible peripheral neuropathies. Multifocal motor neuropathy may cause a chronic distally accentuated motor neuropathy and foot drop, but the symmetrical presentation and family history favor a distal hereditary motor neuropathy (dHMN). The most common form of distal hereditary polyneuropathy is Charcot-Marie-Tooth disease (CMT). CMT is a motor sensory polyneuropathy that by definition has sensory involvement and abnormal sensory nerve action potentials. However, the purely motor symptoms and family history in our

Table Electrodiagnostic (EMG-nerve conduction studies [NCS]) findings

\begin{tabular}{|c|c|c|c|c|c|c|c|c|c|}
\hline Nerve & \multicolumn{2}{|l|}{ Stimulus } & \multicolumn{2}{|c|}{$\begin{array}{l}\text { Recording } \\
\text { site }\end{array}$} & Latency, ms & & \multicolumn{2}{|c|}{$\begin{array}{l}\text { Amplitude (motor }= \\
\mathrm{mV} \text {, sensory }=\mu \mathrm{V})\end{array}$} & $\begin{array}{l}\text { Conduction } \\
\text { velocity, } \mathrm{m} / \mathrm{s}\end{array}$ \\
\hline \multicolumn{10}{|l|}{ Motor NCS } \\
\hline \multirow[t]{3}{*}{ Left ulnar } & \multicolumn{2}{|l|}{ Wrist } & \multicolumn{2}{|c|}{ ADM } & 2.8 & & \multicolumn{2}{|l|}{9.81} & \\
\hline & \multicolumn{2}{|l|}{ Below elbow } & \multicolumn{2}{|c|}{ ADM } & 6.3 & & \multicolumn{2}{|l|}{8.96} & 55.7 \\
\hline & \multicolumn{2}{|l|}{ Above elbow } & \multicolumn{2}{|c|}{ ADM } & 8.2 & & \multicolumn{2}{|l|}{7.38} & 52.6 \\
\hline \multirow[t]{2}{*}{ Left tibial } & \multicolumn{2}{|l|}{ Ankle } & \multicolumn{2}{|c|}{$\mathrm{AH}$} & $6.6^{\mathrm{a}}$ & & \multicolumn{2}{|l|}{$1.5^{\mathrm{a}}$} & \\
\hline & \multicolumn{2}{|l|}{ Popliteal fossa } & \multicolumn{2}{|c|}{$\mathrm{AH}$} & 14.9 & & \multicolumn{2}{|l|}{$0.38^{a}$} & 43.9 \\
\hline \multicolumn{10}{|l|}{ Sensory NCS } \\
\hline Left ulnar & \multicolumn{2}{|l|}{ Wrist } & \multicolumn{2}{|c|}{ Digit V-wrist } & 2.2 & & \multicolumn{2}{|l|}{13} & 50 \\
\hline Left radial & \multicolumn{2}{|l|}{ Forearm } & \multicolumn{2}{|c|}{ Forearm-snuff box } & 2 & & \multicolumn{2}{|l|}{19.6} & 50 \\
\hline \multirow[t]{2}{*}{ Left sural } & Lower leg & & \multicolumn{2}{|c|}{ Ankle-lower leg } & 3 & & \multicolumn{2}{|l|}{5.0} & 40.2 \\
\hline & \multicolumn{3}{|c|}{ Spontaneous activity } & \multicolumn{4}{|c|}{ Motor unit morphology } & \multicolumn{2}{|c|}{ Interference pattern } \\
\hline Muscle & IA & Fibs/PW & Fasc & Duration & Amplitude & Phase & & Activation & Recruitment \\
\hline \multicolumn{10}{|l|}{$\begin{array}{l}\text { Needle EMG } \\
\text { examination }\end{array}$} \\
\hline FDI & Normal & 0 & 0 & Normal & Normal & None & & Normal & Normal \\
\hline VM & Normal & 0 & 0 & $\begin{array}{l}\text { Slight } \\
\text { increase }^{a}\end{array}$ & Normal & None & & Normal & Mildly reduced $(-1)^{a}$ \\
\hline TA & Increased $^{a}$ & $+2^{a}$ & 0 & Normal & Normal & None & & Normal & Severely reduced $(-3)^{a}$ \\
\hline MG & Increased $^{a}$ & $+1^{a}$ & 0 & Normal & Normal & $\begin{array}{l}\text { Slight } \\
\text { increase }\end{array}$ & & Normal & Severely reduced $(-3)^{a}$ \\
\hline
\end{tabular}

Abbreviations: $A D M=$ adductor digitorum minimi; $A H=$ abductor hallucis; Fasc = fasciculation; FDI = first dorsal interosseous; Fibs = fibrillation potentials; IA = insertional activity; MG = medial gastrocnemius; $\mathrm{PW}=$ positive waves; $\mathrm{TA}=$ tibialis anterior; $\mathrm{VM}=$ vastus medius.

${ }^{a}$ Abnormal findings. 
patient lead to a strong suspicion of dHMN, a subtype of hereditary neuropathy with clinical and genetic overlap with CMT. The cardinal feature of $\mathrm{dHMN}$ is a very slowly progressive length-dependent neuropathy often starting in the first 2 decades, ${ }^{2}$ although later onset has been reported. ${ }^{3}$ There are multiple genes associated with dHMN; however, a causative genetic defect can currently only be identified in fewer than $20 \%$ of patients. Bilateral foot drop is only rarely a sole manifestation of a hereditary neuromuscular junction (NMJ) disorder or congenital myasthenic syndrome, and is therefore unlikely. One such recently described congenital myasthenic syndrome/dHMN overlap is due to mutations in synaptotagmin 2 (SyT2), manifesting with distally dominant weakness, foot deformities, and presynaptic NMJ dysfunction on postexercise compound muscle action potential (CMAP) amplitude testing. ${ }^{4}$ Foot drop can be the dominant manifestation of hereditary distal myopathies such as myofibrillar myopathy and GNE myopathy. ${ }^{5}$ Myofibrillar myopathies are clinically and genetically (genes associated include MYOT, DES, CRYAB, ZASP, FLNC, and BAG3) heterogeneous disorders characterized by progressive muscle weakness with typical onset in midadulthood. ${ }^{5}$ GNE myopathy typically presents with weakness of ankle dorsiflexion in early to mid-adulthood. ${ }^{6}$ Differentiating a distal myopathy and dHMN can be challenging. Frequently, initially affected upper extremity muscles include intrinsic hand muscles in $\mathrm{dHMN}$ and forearm/finger flexors in distal myopathies. ${ }^{2}$ However, as in the current case, when the patient presents with isolated foot drop, diagnosis based on phenotype becomes difficult and warrants further evaluation such as electrodiagnostic testing, which can be key for etiologic delineation.

Investigations in our patient revealed a normal serum creatine kinase (CK) level, hemoglobin Alc level, thyroid function, vitamin $B_{12}$, and protein immunofixation electrophoresis. Nerve conduction studies showed a low amplitude tibial CMAP, with otherwise normal motor and sensory conduction studies for age. EMG examination revealed increased abnormal spontaneous activity and severely reduced recruitment of tibialis anterior and medial gastrocnemius muscles (table). These findings were suggestive of chronic axonal neuropathy.

\section{Question for consideration:}

1. What further investigations should be considered?

\section{GO TO SECTION 3}




\section{Section 3}

Based on the clinical presentation, family history, and electrodiagnostic results, dHMN was strongly considered in our patient. He underwent next-generation sequencing and deletion/duplication analysis targeted to genes known to be associated with hereditary neuropathies, which showed a heterozygous variant of unknown significance (p.Pro682Leu; c.2045C>T) in MED25 (mediator complex subunit 25). The MED25 gene is associated with CMT disease type $2 \mathrm{~B}$ (CMT2B). CMT2B is an autosomal recessive axonal neuropathy characterized by distal weakness, mild sensory loss, and normal or near normal nerve conduction velocities. Disease manifestation occurs only in a homozygous or compound heterozygous state, making this an unlikely explanation in our patient. ${ }^{7}$ We proceeded with whole-exome sequencing (WES) for precise diagnosis. WES revealed a heterozygous known pathogenic variant p. Ser60Cys $(c .179 \mathrm{C}>\mathrm{G})$ in the MYOT gene. This has been reported previously in patients with myofibrillar myopathy. This variant is not observed in large population cohorts and functional studies indicate that S60C results in the reduced degradation of myotilin. ${ }^{8}$

\section{Discussion}

The MYOT gene located on chromosome 5q31 encodes myotilin and causes myotilinopathy, which accounts for about $10 \%$ of cases of myofibrillar myopathies. ${ }^{9}$ Myotilin is a sarcomere Z-disk component that interacts with $\alpha$-actinin, filamin C, and actin and plays a role in myofibrillar assembly. It is expressed strongly in skeletal and weakly in cardiac muscles. Mutations in MYOT were first identified in autosomal dominant limb-girdle muscular dystrophy type 1A and subsequently in distal myopathies (myotilinopathy). Distal lower extremity weakness is a common presentation of myotilinopathy, seen in about $80 \%$ of patients, with an age at presentation between 45 and 60 years. Other features include myalgia, muscle cramps, tight heel cords, hyporeflexia, and normal or slightly elevated CK levels. ${ }^{5,10}$ Involvement of the soleus muscle followed by the tibialis anterior and medial gastrocnemius is commonly noted on muscle MRI. EMG shows abnormal spontaneous activity, such as fibrillation potentials, positive sharp waves, complex repetitive discharges, or myotonic discharges. Concomitant peripheral nerve involvement may occur as myotilin is also expressed in peripheral nerve. ${ }^{10}$

Our patient's clinical and electrophysiologic features were suggestive of dHMN. Genetic testing that is focused on a small set of genes known to be associated with the phenotype of interest is rationale and advocated. Nonetheless there can be significant phenotypic overlap between diagnostic categories. In such instances, a broader genetic testing approach can be helpful. WES uncovered the diagnosis of myotilinopathy in our patient with a phenotype mimicking dHMN. In retrospect, EMG findings in our patient could have been consistent with myotilinopathy rather than dHMN. Advanced myopathies may be accompanied by decreased motor unit recruitment, while clear evidence of reinnervated motor units (characteristic of chronic motor neuropathies) was lacking in this patient. Mixed myopathic and neurogenic patterns of motor unit morphology have also been reported with myotilinopathy. ${ }^{10}$ Our patient had no history or symptoms or signs of cardiac dysfunction. However, as asymptomatic cardiomyopathy has been described with myotilinopathy, ${ }^{10}$ screening echocardiography was included in care recommendations. Muscle biopsy could provide additional insights pertaining to distinction between a dHMN, distal myopathy, or a combination thereof. However, muscle biopsy was not pursued in our patient as it would not have affected the diagnosis of myotilinopathy or management.

Distal myopathies such as myotilinopathy should be considered when evaluating a patient with isolated foot drop. A proportion of cases of suspected dHMN may actually be distal myopathies, and broader genetic testing targeting distal myopathies as well as dHMN can be considered when evaluating such patients.

\section{Study funding}

No targeted funding reported.

\section{Disclosure}

Y. Harada and S. Zuchner report no disclosures relevant to the manuscript. D. Herrmann receives grant support through NIH U54 NS065712-09, 1U01NS109403-01, the Muscular Dystrophy Association, the Friedreich's Ataxia Alliance, and Voyager Pharmaceuticals, and has received compensation for scientific consulting activities in the past 3 years from Acceleron, Inc., Alnylam, Neurogene, Flex Pharma, Regenacy, Inc., Guidepoint Global, Gerson Lehrman Group, Slingshot Insights, Clear View Health Partners, Trinity Partners, Cydan, Schlesinger, Human First Therapeutics, Narrow River Management, and Medpace. A. Veerapandiyan reports no disclosures relevant to the manuscript. Go to Neurology.org/N for full disclosures.

\section{Appendix Authors}

\begin{tabular}{llll}
\hline Name & Location & Role & Contribution \\
\hline $\begin{array}{l}\text { Yohei Harada, } \\
\text { MD }\end{array}$ & $\begin{array}{l}\text { University of } \\
\text { Arkansas for } \\
\text { Medical Sciences, } \\
\text { Little Rock }\end{array}$ & Author & $\begin{array}{l}\text { Data collection, } \\
\text { drafting and } \\
\text { revising manuscript } \\
\text { and table }\end{array}$ \\
\hline $\begin{array}{l}\text { Stephan L. } \\
\text { Zuchner. MD }\end{array}$ & $\begin{array}{ll}\text { University of } \\
\text { Miami, FL }\end{array}$ & Author & $\begin{array}{l}\text { Revising the } \\
\text { manuscript, study } \\
\text { concept }\end{array}$ \\
$\begin{array}{l}\text { David N. } \\
\text { Herrmann, } \\
\text { MBBCh }\end{array}$ & $\begin{array}{l}\text { University of } \\
\text { Rochester Medical } \\
\text { Center, NY }\end{array}$ & Author & $\begin{array}{l}\text { Cared for the } \\
\text { patient, study } \\
\text { concept, revising } \\
\text { manuscript }\end{array}$ \\
\hline $\begin{array}{l}\text { Aravindhan } \\
\text { Veerapandiyan, } \\
\text { MD }\end{array}$ & $\begin{array}{l}\text { University of } \\
\text { Arkansas for } \\
\text { Medical Sciences, } \\
\text { Little Rock }\end{array}$ & Author & $\begin{array}{l}\text { Cared for the } \\
\text { patient, study } \\
\text { concept, revising } \\
\text { manuscript }\end{array}$ \\
\hline
\end{tabular}




\section{References}

1. Kim WK, Liu X, Sandner J, et al. Study of 962 patients indicates progressive muscular atrophy is a form of ALS. Neurology 2009;73:1686-1692.

2. Rossor AM, Kalmar B, Greensmith L, Reilly MM. The distal hereditary motor neuropathies. J Neurol Neurosurg Psychiatry 2012;83:6-14.

3. James PA, Rankin J, Talbot K. Asymmetrical late onset motor neuropathy associated with a novel mutation in the small heat shock protein HSPB1 (HSP27). J Neurol Neurosurg Psychiatry 2008;79:461-463.

4. Herrmann DN, Horvath R, Sowden JE, et al. Synaptotagmin 2 mutations cause an autosomal-dominant form of Lambert-Eaton myasthenic syndrome and nonprogressive motor neuropathy. Am J Hum Genet 2014;95:332-339.

5. Olive M, Goldfarb LG, Shatunov A, Fischer D, Ferrer I. Myotilinopathy: refining the clinical and myopathological phenotype. Brain 2005;128:2315-2326.
6. Asaka T, Ikeuchi $\mathrm{K}$, Okino S, et al. Homozygosity and linkage disequilibrium mapping of autosomal recessive distal myopathy (Nonaka distal myopathy).J Hum Genet 2001;46:649-655.

7. Leal A, Huehne K, Bauer F, et al. Identification of the variant AL335Val of MED25 as responsible for $\mathrm{CMT} 2 \mathrm{~B} 2$ : molecular data, functional studies of the $\mathrm{SH} 3$ recognition motif and correlation between wild-type MED25 and PMP22 RNA levels in CMT1A animal models. Neurogenetics 2009;10:275-287.

8. von Nandelstadh P, Soliymani R, Baumann M, Carpen O. Analysis of myotilin turnover provides mechanistic insight into the role of myotilinopathy-causing mutations. Biochem J 2011;436:113-121.

9. Maerkens A, Olive M, Schreiner A, et al. New insights into the protein aggregation pathology in myotilinopathy by combined proteomic and immunolocalization analyses. Acta Neuropathol Commun 2016;4:8.

10. Selcen D, Engel AG. Mutations in myotilin cause myofibrillar myopathy. Neurology 2004;62:1363-1371.

\section{Subspecialty Alerts by E-mail!}

Customize your online journal experience by signing up for e-mail alerts related to your subspecialty or area of interest. Access this free service by clicking on the "My Alerts" link on the home page. An extensive list of subspecialties, methods, and study design choices will be available for you to choose from-allowing you priority alerts to cutting-edge research in your field!

\section{Quality Improvement: Start Small to Make Big Changes}

You deliver excellent patient care, but there is always room for improvement. In health care, quality improvement (QI) is the framework used to systematically improve the ways care is delivered to patients. Learn how to increase desired health outcomes. Browse AAN resources to help you drive change at AAN.com/view/QI.

\section{Sign Up for the AAN's Axon Registry}

The AAN encourages its US members to show their interest in participating in the Axon Registry。 by signing up today.

Use the Axon Registry to:

- Simplify reporting requirements under MACRA's Quality Payment Program and avoid penalties while reducing your administrative burden

- Meet your MOC Part IV requirements and waive up to eight credits of Part II Self-Assessment

- Choose from 22 AAN neurology-specific quality measures that fit your practice

- Use data to understand your practice and identify where improvements can be made to patient care

- Manage your patients at a population level; look at a specific group of patients based on conditions, risk factors, demographics or outcome

- Demonstrate your value to payers when negotiating reimbursement

- Enjoy multi-year, fee-free access when you sign the agreements and integrate your EHR with the registry

Learn more at AAN.com/view/Axon and send your questions to registry@aan.com. 


\section{Neurology}

\section{Clinical Reasoning: A case of bilateral foot drop in a 74-year-old man}

Yohei Harada, Stephan L. Zuchner, David N. Herrmann, et al.

Neurology 2020;94;405-409 Published Online before print February 10, 2020

DOI 10.1212/WNL.0000000000008760

This information is current as of February 10, 2020

\section{Updated Information \&} Services

References

Subspecialty Collections

\section{Permissions \& Licensing}

Reprints including high resolution figures, can be found at: http://n.neurology.org/content/94/9/405.full

This article cites 10 articles, 5 of which you can access for free at: http://n.neurology.org/content/94/9/405.full\#ref-list-1

This article, along with others on similar topics, appears in the following collection(s):

\section{All Genetics}

http://n.neurology.org/cgi/collection/all_genetics

All Neuromuscular Disease

http://n.neurology.org/cgi/collection/all_neuromuscular_disease

\section{EMG}

http://n.neurology.org/cgi/collection/emg

Muscle disease

http://n.neurology.org/cgi/collection/muscle_disease

Peripheral neuropathy

http://n.neurology.org/cgi/collection/peripheral_neuropathy

Information about reproducing this article in parts (figures,tables) or in its entirety can be found online at:

http://www.neurology.org/about/about_the_journal\#permissions

Information about ordering reprints can be found online:

http://n.neurology.org/subscribers/advertise

Neurology ${ }^{\circledR}$ is the official journal of the American Academy of Neurology. Published continuously since 1951, it is now a weekly with 48 issues per year. Copyright @ 2020 American Academy of Neurology. All rights reserved. Print ISSN: 0028-3878. Online ISSN: 1526-632X.

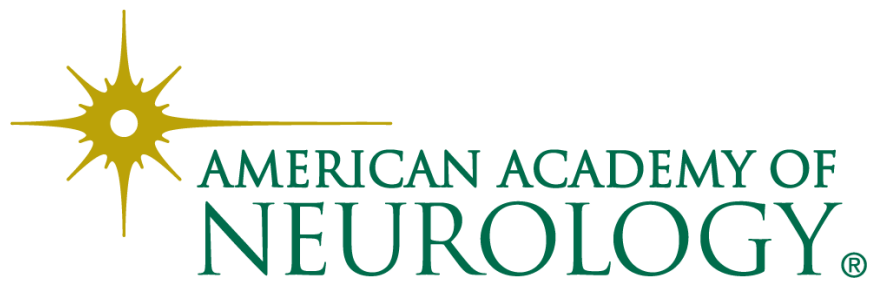

